\author{
Mario Vrbančić \\ Sveučilište u Zadru, Obala kralja Petra Krešimira IV. br. 2, HR-23000 Zadar \\ mario_exile@yahoo.co.nz
}

\title{
Kralj bez tijela i njegova sjena
}

\section{Prema političkoj teologiji filma}

\begin{abstract}
Sažetak
Inspiriran radom Erica Santnera $(1996,2011)$ o političkoj teologiji i kraljeva dva tijela, u ovom radu propitujem političku teologiju filma, tj. kako drugo tijelo kralja, tijelo njegove moći, migrira u novo tijelo, tijelo naroda, te sablasno, u raznim tragovima, prati filmski način proizvodnje koji je obilježio dvadeseto stoljeće. U radu dovodim u imaginarnu vezu dva lika (jedan stvarni, drugi fiktivni) koji na određeni način utjelovljuju to migriranje: (1) sudca Daniela Paula Schrebera (čiji je autobiografski zapis mentalne bolesti, od trenutka kada je objavljen 1903., okupirao pažnju ne samo psihijatara i psihoanalitičara nego $i$ raznih teoretičara), i (2) doktora Caligarija, hipnotizera u filmu Kabinet doktora Caligarija (red. Robert Wiene, 1920.), jednog od najpoznatijih junaka njemačkog ekspresionističkog filma, kako bih analizirao kako njihovi slučajevi utjelovljuju »sublimno rojalističko meso" u nacionalnim fantazmagorijama dvadesetoga stoljeća (koje se sve više vraćaju i u naše vrijeme u doba rastućeg populizma i brojnih teorija zavjere).
\end{abstract}

\section{Ključne riječi}

politička teologija filma, kraljeva dva tijela, biomoć, kinematički način proizvodnje, psihoanaliza

Slika Maratova smrt Jacquesa Louis Davida iz 1793. godine po Clarkovu je mišljenju inauguracijska slika modernizma. Slika prikazuje smrt Jeana-Paula Marata, jednog od revolucionarnih vođa jakobinaca kojeg je 13. 7. 1793. u kadi ubila Charlotte Corday, pripadnica žironde, poražene političke grupe čiji su se članovi za vrijeme Francuske revolucije protivili masovnim egzekucijama. Sliku je naručila jakobinska francuska vlada, a za mnoge je suvremene povjesničare umjetnosti (bez obzira na različite interpretacije same slike) $M a$ ratova smrt jedna od najpoznatijih slika Francuske revolucije. ${ }^{1}$

Na slici, iza smrtno-ranjenog izblijedjelog Maratova tijela, nalazi se sivo-crna pozadina koja, po Clarkovu mišljenju, kao da upućuje na nemogućnost prikaza nadolazećih događaja - vladavinu naroda, nacija, masa, mnoštva. ${ }^{2}$ Maratovo tijelo, iako je za jedne predstavljalo zlo, a za druge dobro, trebalo je, po Clarku, zamijeniti kraljevo tijelo (prazno mjesto kralja), otjeloviti revoluciju,

Amy Ione, Art and the Brain: Plasticity, Embodiment and the Unclosed Circle, Brill Rodopi, London 2016., str. 203.

2

Usp. Timothy James Clark, Farewell to an Idea: Episodes from a History of Modernism, Yale University Press, New Haven 1999., str. 36-47; Timothy James Clark, »Painting in the
Year Two«, Representations 47 (1994), str. 1363, doi: https://doi.org/10.2307/2928785; Eric L. Santner, »Was heist Schauen? On the Vital Signs of Visual Modernism«, u: Eric L. Santner, The Royal Remains: The People's Two Bodies and the Endgames of Sovereignty, The University of Chicago Press, Chicago 2011., str. 89-141. 
nadići naizgled bezizlaznu situaciju nemogućnosti predstavljanja 'istine' koja bi zadovoljila sve uključene strane. Drugim riječima, kao što to tvrdi Clark, čin svrgavanja kralja s prijestolja, u svojim širim konzekvencama, mijenja kut gledanja koji traje do današnjih dana, u tijelo Marata upisuje se političko, ono postaje svojevrsna apstrakcija, kao i praznina iza njega.

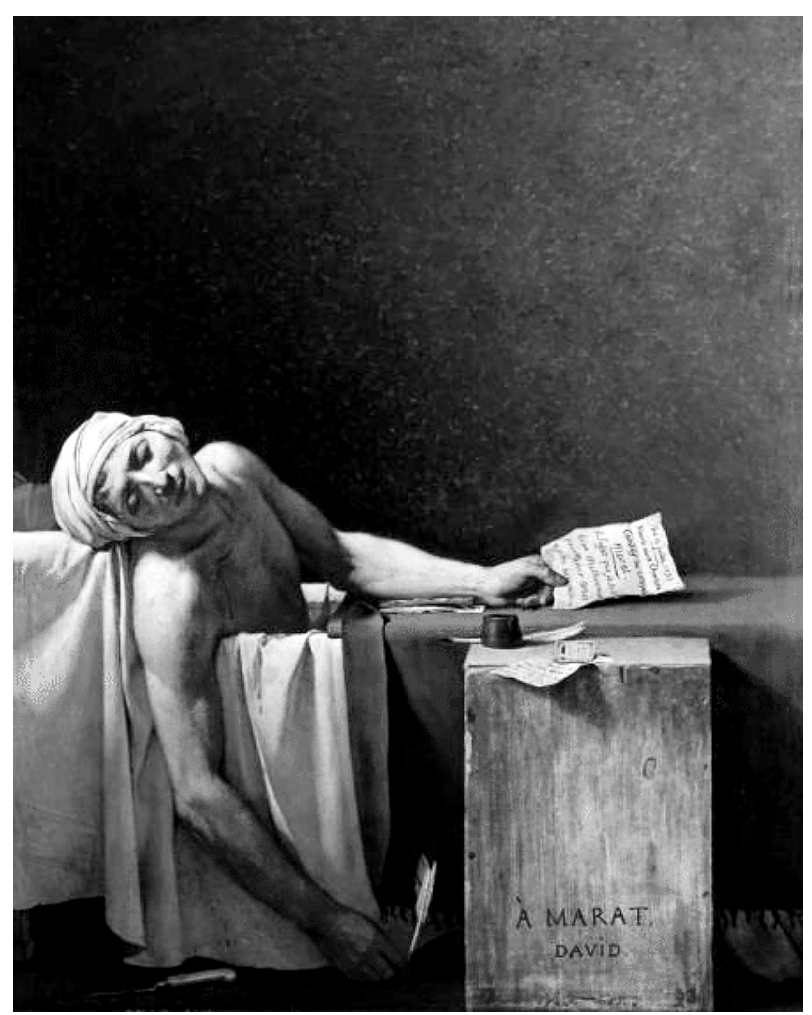

Slika 1: Jacques-Louis David, Maratova smrt (Marat assassine), 1793. Ulje na platnu, $165 \times 128 \mathrm{~cm}$. Kraljevski muzej umjetnosti u Belgiji (Musees Royaux des Beaux-Arts de Belgique). ${ }^{3}$

Za Erica L. Santnera, Maratova smrt predstavlja fundamentalnu nemogućnost prikazivanja, otvara put biopolitičkoj teologiji suvereniteta, u kojoj čin svrgavanja kralja sablasno prati bilo koju predodžbu pa i polje vizualnog. ${ }^{4}$ Pozivajući se na tezu Kantorowitcza o kraljevu drugom tijelu - tj. o tijelu-u-tijelu, to drugo tijelo nije podložno starenju, bolestima, raspadanju, nego je ono vječno, sublimno tijelo, božansko tijelo koje omogućuje objedinjavanje svih podanika - Santner razmatra političku teologiju narodne suverenosti. ${ }^{5}$ Sam koncept političke teologije, kako tvrdi Santner, u sebi sadrži prijepor. S jedne strane, odnosi se na ekspanziju religioznih vrijednosti koje prodiru u politički život i političke institucije pa se akteri često ponašaju kao da su 'zarobljeni' karizmom svetog autoriteta. S druge strane, označava područje u kojem je religiozno potisnuto u sferu 'privatnog'. Politička teologija, stoga, s jedne strane, može biti viđena kao sekularizacija, dislokacija religije kao središnjeg mjesta društvenog i kolektivne identifikacije, a s druge strane, političko se omogućava upravo s teološkim konceptima i sustavom vrijednosti. ${ }^{6}$

»Prelazak s političke teologije kraljevske suverenosti na sekularizirane političke teorije narodne suverenosti (i forme života uokvirene tom suverenošću) postavlja kroz nove modalitete ambivalentnost u prvi plan. $\ll^{7}$ 
Foucaultovski rečeno, kolektivno življenje postaje scena koja je administrirana i disciplinirana. Za Foucaulta, biomoć oblikuje suverenost, ona je moć reguliranja života, autoritet koji forsira život ne samo kao puko življenje nego življenje na određeni način, tj. regulativno se odnosi na zdravlje populacije. Po Santnerovu mišljenju, ono što je značajno u prelasku kraljevske suverenosti na narodnu suverenost ne odnosi se samo na biološki život ili zdravlje populacije, kao što to tvrdi Foucault, »nego na sublimnu životnu supstanciju onog što čini narod «. ${ }^{8}$

Inspiriran Santnerom, u ovom radu propitujem kako taj čin svrgavanja kralja, tj. »drugo tijelo kralja« - tijelo njegove moći koje migrira u novo tijelo, tijelo naroda, sablasno, u raznim tragovima - prati filmski način proizvodnje koji je obilježio dvadeseto stoljeće. Filmski način proizvodnje termin je koji se oslanja na Bellerov koncept »kinematičkog načina proizvodnje «. ${ }^{9} \mathrm{Za}$ Bellera, kinematički način proizvodnje istovremeno je organizacijska paradigma društvenih odnosa i nužnih tehnika koje proizvode i strukturiraju percepcije, tj. moderne subjekte. Preuzimam gotovo isti termin, ali ga mijenjam jer se atribut filmski odnosi i na ono što je filmično, tj. film prije filma, filmska percepcija stvarnosti. Smatram da filmski način proizvodnje (u kojem se ne radi samo o proizvodnji priča, emocija, filmskih slika itd. nego i o proizvodnji publike, gledateljstva, subjekata), pokušava osjetilno udomiti kako pojedince tako i mase u modernom svijetu, tj. upotpuniti prazninu iza mrtvoga Marata, prazninu koja za Santnera predstavlja višak imanencije koja iz kraljeva dva tijela (prirodno i političko) sa svim svojim kompleksnostima prelazi u tijelo naroda ili, bolje rečeno, dva tijela naroda. Taj imanentni višak koji je nemoguće prikazati Santner naziva »mesom« ili, lacanovskim rječnikom rečeno, to bi bio preostatak nepodnošljivog Realnog. ${ }^{10} \mathrm{Za}$ mene, ta praznina predstavlja nultu točku političke teologije filma, imaginarni minimum na kojem može počivati bilo koji oblik zajednice, nepodnošljiva apstrakcija koja se neprestano prevodi u razne figuracije, u nove filmove. Možemo reći da praznina iza Maratova tijela prethodi, ali i proizvodi razne ideološke obrasce, sukobljene svjetonazore, koji kovitlaju u najširem filmskom kadru, tj. okviru Zakona i Države, drugim riječima, kao nešto nevidljivo što omogućava vidljivo, kao nulta točka društva spektakla.

U radu analiziram ili, bolje rečeno, dovodim u imaginarnu vezu dva lika (jedan stvarni, drugi fiktivni) koji na određeni način utjelovljuju tu nultu točku: (1) sudca Daniela Paula Schrebera (čiji je autobiografski zapis mentalne bolesti, od trenutka kada je objavljen 1903., okupirao pažnju ne samo psihijatara i psihoanalitičara nego i raznih teoretičara), ${ }^{11}$ i (2) doktora Caligarija, hipnotizera

3

Dostupno na: https://www.fine-arts-museum. be/fr/la-collection/jacques-louis-david-marat-assassine (pristupljeno 10. 3. 2020.).

4

E. L. Santner, »Was heist Schauen?«, str. 93, 141.

5

E. L. Santner, The Royal Remains, xii.

Ibid.

Ibid.
8

Ibid.

Usp. Jonathan Beller, Kinematički način proizvodnje: ekonomija pažnje i društvo spektakla, preveo Snježan Hasnaš, Naklada Jesenski i Turk, Zagreb 2016.

10

E. L. Santner, The Royal Remains, str. 18-19. 11

Schreberovim memoarima bavili su se, među ostalima, Freud, Benjamin, Canetti, Deleuze, Foucault, Certau, Lacan i Kittler. Vidi: Eric. L. Santner, My Own Private Germany: Daniel 
u filmu Kabinet doktora Caligarija (Das Cabinet des Dr. Caligari, red. Robert Wiene, 1920.), jednog od najpoznatijih junaka njemačkog ekspresionističkog filma. ${ }^{12}$ Da bismo uopće mogli govoriti o uzajamnoj, imaginarnoj vezi između sudca Schrebera i hipnotizera Caligarija, moramo odbaciti teologiju povijesti koja kao pravolinijski progres neumitno, željeznom logikom, vodi do današnjeg stanja. To teološko ispunjenje smisla, to »vođenje do današnjeg stanja« ujedno implicira »da ionako nikako drukčije nije moglo biti«, sve verzije prošlosti, svi rukavci vremena slijevaju se u jedan tijek. Da bismo omogućili ili barem djelomično razumjeli Caligarijev i Schreberov susret, trebali bismo naći rupu u povijesti, »iščašenost vremena« (time out of joint), slijepu ulicu koja se kristalno reflektira u nedogled - zapravo »nemogući« moment u kojem se može izbjeći nužnost ulančavanja povijesnog narativa. Ako zamišljeni susret Schrebera i Caligarija sadrži tajnu, onda je ona na neki način vezana za mutacije suverene moći i njezinih institucija, mutacije koje su značajne i za nas danas. Stoga su pitanja na koja pokušavam odgovoriti u ovom radu, kroz zamišljeni susret Schrebera i Caligarija sljedeća: u kojoj mjeri Schreber i Caligari utjelovljuju mutacije »ostataka rojalističkog tijela«, umrežene raznim oblicima moći utjelovljenim u birokratskim institucijama i znanjima eksperata? Kako njihovi slučajevi utjelovljuju »sublimno rojalističko meso« u nacionalnim fantazmagorijama dvadesetoga stojeća (koje se sve više vraćaju i u naše vrijeme u doba rastućeg populizma i brojnih teorija zavjere). I konačno, kako nam Schreber i Caligari ukazuju na političku teologiju filma danas?

\section{Paranoični sudac Schreber kao filmski redatelj}

Daniel Paul Schreber, njemački sudac, postaje slavan kao jedan od najtežih »pacijenata« Sigmunda Freuda koji ga nikad nije vidio, ali se detaljno bavio njegovim memoarima. ${ }^{13}$ Rođen je 1842 . u Leipzigu. Završio je studij prava i radio u javnoj upravi za vrijeme francusko-pruskog rata (1870. - 1871.). Godine 1878. Schreber postaje administrativni upravitelj suda u Chemnitzu, a 1884. bio je istaknut kao kandidat Nacionalne liberalne stranke za Reichstag. Izbore je izgubio i tad je zabilježen njegov prvi živčani slom te hospitalizacija u psihijatarskoj bolnici u Leipzigu. Njegov psihijatar bio je Emil Flechsig. Nakon otpuštanja iz bolnice, Schreber je punih osam godina radio kao saksonski (saski) sudac. Njegovi psihički problemi ponovo su se pojavili 1893., kad je aplicirao za poziciju vrhovnog sudca, a nakon imenovanja, psihički su problemi eskalirali na razne načine (insomnija, suicidalne misli itd.). Ponovno je hospitaliziran, ali tada počinju njegove paranoje koje se odnose na božanske zrake i jezik nerva:

»Božanske zrake iznad svega imaju moć utjecaja nad ljudskim nervima: na taj način Bog je s lakoćom donio snove ljudskim bićima. Ja sam prvi osjetio taj utjecaj preko profesora Flechsiga. Jedino moguće objašnjenje koje mi pada na pamet jest da je profesor Flechsig spoznao način kako da koristi te božanske zrake za svoje posebne potrebe (...). « ${ }^{14}$

Santner ističe kako su Schreberove deluzije barem djelomično uzrokovane »otkrivenjem« riječi, performativnošću jezika, tj. materijalizacijom jezika. U svojim Memoarima Schreber povezuje svoje osobne probleme s političko-teološkim motivima, naglašavajući i političke i religiozne događaje koji su postali dio njegovih vizija. ${ }^{15}$ Ono što je Schreber otkrio, po Santnerovu mišljenju, libidinalna je nemogućnost identifikacije sa simboličkim (prostorom u kojem dolazimo u dodir jedni s drugima u našim uredima, zvanjima, simboličkim mandatima itd.). Ta je nemogućnost učinkovito transformirala njegovo 
tijelo koje je potom »izručeno psihijatriji, jednoj od ključnih institucija kojom se bavio Foucault u svom proučavanju biopolitičke moći, instituciji čije je razumijevanje mentalne bolesti bilo usredotočeno na neurološki poremećaj «. ${ }^{16}$ Ukratko, Schreber je svoju »metamorfozu« shvaćao kao nešto što je uglavnom povezano s društvenom transformacijom, nešto što politički određuje njegov prostor predodžbe i svrstava ga u »drugost«. Po Santnerovu mišljenju, prostor predodžbe uvijek je bio jedna od domena u kojoj je implicirano meso (libidinalno). U doba klasične političke teologije, označitelji koji predstavljaju subjekt u mreži označitelja (zajednici) podržani kraljevim »sublimnim mesom « (sacral soma) osiguravaju i osnažuju osjećaj pripadnosti. Takva libidinalna poveznica $u$ post-monarhističkim društvima nestaje, $t \mathrm{j}$. preobražava se u narodnu suverenost, a političko-teološki aspekt postaje birokratiziran. Takvo stanje dovodi do užasavanja i propitivanja (ne)utemeljenosti političkog autoriteta, tj. postavlja se pitanje o tome na koji način birokracija ulazi u nas same, legitimira naše osjećaje pripadanja zajednici. ${ }^{17}$ Nemogućnost utemeljenja božanskog u Zakonu ukazuje na trulost Zakona na kojim počivaju institucije modernosti (birokracija, znanje eksperata), tj. dovodi do posebne bolesti autoriteta na kojoj počivaju te institucije. Ta neutemeljenost zakona vodi do strašne tautologije - Zakon je Zakon - kronične ugroze i nestabilnosti institucija. Na kraju i u samom Zakonu, jer se ne može nikako utemeljiti, uvijek nešto nedostaje, tj. u samom Zakonu ima nešto trulo.

Po Santnerovu mišljenju, upravo je trulež Zakona (raznih institucija) očitovana u Schreberovu slučaju. Njegova dijagnoza tiče se krize institucija moderne države koju Schreber osjeća u svome tijelu. Schreberova ispovijest proizlazi iz prožimanja političke teologije suvereniteta i biopolitike, tj. strategije s kojom se u modernim društvima osigurava meso (libidinalno). Schreber - izabrani spasitelj svijeta preobražen u božansku konkubinu - sluša razne božanske glasove ili je sam božji trbuhozborac, njegovo tijelo postaje božansko trulo meso u koje se strovaljuju službene institucije i birokracija. To tijelo, kako tvrdi Santner, odražava napetosti i prijepore političke teologije pod pritiskom birokracije i novih oblika moći (biomoći) te postaje metafora stanja u modernizmu.

Tu, u najdubljem vrtlogu Schreberovih noćnih mora, vidim i sam izvor proizvodnje filmskih slika, vidim Schrebera kao filmskog redatelja. Naravno, kada govorim o Schreberu kao filmskom redatelju mislim na filmično. Filmično nije izravno vezano s filmom kao takvim. Tako, na primjer, Wilhelm S. Wurzer tvrdi da se povijest filozofije od Platona do Spinoze (i šire) može gledati kao genealogija »filmskoga bilježenja«, tj. kao povijesna tendencija svijesti. ${ }^{18}$ Po njegovu mišljenju, metafizika je dosljedno potiskivala shvaćanje

Paul Schreber's Secret History of Modernity, Princeton University Press, Princeton 1996., str. ix.

12

Usp. Siegfried Kracauer, From Caligari to Hitler. Psychological History of German Film, Princeton University Press, Princeton 2004.

13

Usp. E. L. Santner, My Own Private Germa$n y$, str. 1-9.

14

E. L. Santner, The Royal Remains, str. 34.
15

E. L. Santner, My Own Private Germany, str. 104.

16

E. L. Santner, The Royal Remains, str. xiv.

17

Ibid., str. xv.

18

»Čitavu povijest filozofije barem od Platona do Spinoze dosljedno je potiskivala slikovito predočavanje, tj. nefotologocentrični način prosuđivanja koji razjašnjava postmodernu 
slikovnog predočavanja i zatočila je njegovu važnost u logocentričnom gledištu razuma. ${ }^{19}$ Svakako je najslavniji filozofski zastupnik 'filmičnoga' Henri Bergson, čija je filozofija bila itekako utjecajna na filmske teorije i studije te se posebno plodonosnom pokazala svojim utjecajem na Gillesa Deleuzea.

U slučaju Schrebera, filmično vidim ne kao vizualno imaginiranje materije, već kao slučaj institucija, tj. filmično vidim u krizi institucija, u procesu obezimenovanja (unnaming) te pokušaja ponovnog imenovanja, tj. stvaranja svijeta iz truleži raspadajućeg Zakona. ${ }^{20}$ Utoliko je za mene Schreber filmski redatelj ili, bolje, projekcionist, onaj koji projicira film na filmsko platno, štoviše on ne projicira samo ovozemaljsku svijetlost nego i same »božanske zrake« na filmsko platno koje često zovemo svijet. »Božanske zrake« kao zrake koje donose film nisu samo metafora platonske provenijencije o spilji i sjenama, tj. o ‘vječnom' filozofskom pitanju o biću i prividu, tj. o spoznajnom, gnoseološkom problemu, nego i ukazuju na opasno približavanje institucija intimi pojedinca. Santner naglašava kako u tom zadiranju institucija u najdublju intimnost subjekta ne dolazi samo do jačanja autoriteta nego i do narušavanja distance, gubljenja društvenosti, socijalnog prostora, do uranjanja institucija u samu unutrašnjost. To zagušljivo poništavanje distance - paradoksalno premda stvara privid jačanja institucija, ujedno dovodi i do imanentne krize autoriteta. Ta kriza institucija, pojačana s gubljenjem simboličnog razmaka, može se dovesti u vezu s filmskim načinom proizvodnje: što li je drugo snoliki doživljaj filma nego li prikriveno upadanje čitave jedne mašinerije - od filmske tehnologije, glumaca, producenata, tekstopisaca, filmskoga seta, svih trzavica, prepirki, buke, prenemaganja - u nečiju glavu, u intimu gledatelja ili gledateljice. Kao i psihijatrija, ili religiozni rituali ispovijedanja, film je ambivalentno područje - ispremreženo političkom teologijom suvereniteta, biopolitikom o kojoj govori Santner.

Zalaženjem birokracije i institucija (filma) u najdublje intimne misli pojedinca ruši distancu, odmak na kojem počiva simbolički poredak, dovodi subjekt u opasnost gubljenja granica, utvrda, samosvojnosti - izlaže ga zlokobnim silama, hipnotičkim moćima, tj. posebnoj suverenosti koja naizgled počiva na fantaziji. Hipnotička suverenost nastoji ovladati podsviješću pojedinca. Tako, na primjer, Schreber u tom odnosu nije samo redatelj koji režira nego je i redatelj koji ima svoga redatelja - profesora Flechsiga, koji pak zauzima neupitno mjesto Gospodara; možemo reći, dokle god su u pitanju odnosi moći, makar i u najrudimentarnijem obliku, još uvijek smo u društvenim odnosima pa čak i u teološkom smislu odnosa Stvoritelja i stvorenja u proizvodnji filmskih svjetova. Schreber je tako redatelj koji je režiran, projekcionist koji je projiciran, nakaradna parodija Platonovih igara sjena. U tom kontekstu filmično nikada nije u balansu; ono se javlja u izvanrednom stanju u vidu demonskog gospodara, tiranina, kakvim obiluje njemački ekspresionizam, kao dvojnik (sam film kao dvojnik povijesti); kao odraz u zrcalu ili sjena koja se odvaja od tijela te poput dvojnika želi perfidno ovladati nosiocem odraza, tijelom koje je podarilo sjenu ili se u potpunosti odvaja u oživljenoj materiji, kao čudovište. Sve te pojavnosti, koje se već daju naslutiti kod Schrebera, prikrivaju trulost Zakona, podsvjesno birokracije i njezine uloge u stvaranju modernog subjekta. 


\section{Čudovišta i birokracija}

Schreberove fantazije, paranoične vizije oživjet će u novom, ekspresivnom sredstvu par desetljeća nakon njegovih memoara - u Weimarskoj Republici, u filmovima, koje će Kracauer u svojoj slavnoj knjizi From Caligari to Hitler: Psychological History of German Film, kao što i sam naslov kaže, povezati s nacizmom i totalitarizmom. Film za njega posjeduje neviđenu snagu anticipacije budućih događaja: tako Nibelungen I i II (red. Gottfried Huppertz, 1924.) prethode Goebbelsovoj propagandi, Metropolis (red. Fritz Lang, 1927.) Goebbelsovoj viziji velegrada, a moćni hipnotizer Caligari (Kabinet doktora Caligarija, red. Robert Wiene, 1920.) samom Hitleru. ${ }^{21}$ U svojevrsnom déjà $v u$ doživljaju, masovni spektakli crnokošuljaša, stupanje tisuća nogu u istom ritmu već su bili viđeni i prije dolaska nacista na vlast (npr. nacističko salutiranje s ispruženom rukom i uzvikom Heil Hitler inspirirano je starim rimskim pozdravom). ${ }^{22}$

Politička teologija filma za Kracauera je pravolinijski progres koji neumitno vodi mnoštvo ljudskih tijela u jedno, jedinstveno tijelo vođe - Hitlera. Otjelovljenje $u$ jednom tijelu asocira na stare vidove političke teologije u kojima monarhovo tijelo objedinjava svjetovnu i duhovnu vlast, $\mathrm{s}$ tom razlikom da je to objedinjavanje omogućeno novim ulogama državnih institucija, birokracije i novih oblika moći koje se javljaju u modernizmu. Za Kracauera, čitav taj proces predstavlja alegoriju o »patnji njemačke duše« i ta patnja, što mi se čini puno zanimljivije, utjelovljena je u raznim čudovištima i čudovišnostima. Hitleru, dakle, prethode razni oblici čudovišnosti koji će se na kraju obuzdati ili pretvoriti u bezosjećajnu mašinu državnog aparata. Izdvojit ću neka od njih koje Kracauer spominje u prvom dijelu knjige pod nazivom »Arhaični period: 1895. - 1918. «. ${ }^{23}$

Čudovišnost 1: u Praškom studentu (Der Student von Prag, red. Paul Wegener i Stellan Rye, 1913.), siromašni student Baldwin potpisuje ugovor s čarobnjakom Scapinellijem, u kojem se Scapinelli obvezuje da će ispuniti sve studentove želje (ženidba, bogatstvo) pod uvjetom da mu proda svoj odraz u ogledalu. Taj se odraz u ogledalu osamostaljuje, počinje živjeti za sebe i raditi protiv Baldwina i, kada na kraju praški student puca u ogledalo, u trenu rasprsnuća shvaća da je ubio samoga sebe.

Čudovišnost 2: Golem (red. Paul Wegener i Carl Boese, 1915.) adaptira staru srednjovjekovnu legendu u kojoj praški rabin Loew udahnjuje život figuri oblikovanoj od komada gline. U filmu, vlasnik Golema, sada u modernom vremenu, trgovac je antikvitetima i umjetninama. Ponovno oživljeni Golem proživljava sličnu priču kao i nekad davno: zaljublju-

međuigru mišljenja i mašte.« - Prema: J. Beller, Kinematički način proizvodnje, str. 60. 19

Prema: ibid., str. 61.

20

Filmično za mene u tom kontekstu označava retroaktivno filmski potencijal i prije tehnološkog otkrića filma (npr. Eisensteinova čitanja literarnih klasika kao potencijalni filmski scenariji).
21

Leonardo Quaresima, "Introduction", u: S. Kracauer, From Caligari to Hitler, str. xv-1, str. xxxviii.

22

»Božanske zrake« suverene hipnotičke moći imaju, dakle, i određenu temporalnu dimenziju: ne utječu samo izravno na događaje nego ih i anticipiraju.

23

S. Kracauer, From Caligari to Hitler, str. $15-35$. 
je se u trgovčevu kćer, biva odbačen od svih, u osvetničkom pohodu bijesno razara grad, da bi na kraju, nakon pada s visokoga tornja, opet završio u fragmentima beznačajne, gnjecave gline.

Čudovišnost 3: svojevrsna verzija Golema opet se pojavljuje u filmu Homunculus (red. Otto Rippert, 1916.). Ovaj put čudovište je proizvedeno u znanstvenom laboratoriju, ali isto kao i u Golemu, neshvaćen je od ljudi, zamrzi čovječanstvo i prepušta se osvetničkom bijesu. Jedina je razlika što Homunculus, za razliku od Golema, zavlada udaljenom zemljom i postaje diktator, što navodi Kracauera na napomenu o tome kako je to direktna anticipacija Hitlera.

Čudovišnost 4: četvrti je »arhaični film« adaptacija kazališnoga teksta inspiriranog podvojenom ličnošću Dr. Jekyll i Mr. Hyde, Drugi (Der Andere, red. Max Mack, 1913.), u kojem dr. Hallers nakon nesreće (pada s konja) počinje dugo spavati i u snovima se preobrazi u Drugog koji se upušta u noćnu avanturu i pljačku (pa tako s lopovom pljačka svoju kuću).

U navedenim filmovima, hipnotička suverena moć dolazi u doticaj ili oživljava stare ili strane, prijeteće oblike života. U kolopletu čudovišta i čudovišnosti središnje mjesto zauzima lik dr. Caligarija iz poslijeratnog filma Kabinet doktora Caligarija. ${ }^{24}$ Premda je u mnogočemu sličan prijašnjim čudovišnostima, najviše se od ostalih razlikuje, možda, po narativnoj strategiji: priča nije ispričana izravno, već je uokvirena drugom pričom, dakle, kao što imamo tijelo-u-tijelu, tako ovdje imamo priču-u-priči.

Filmski plot: Francis govori o tome kako je sreo dr. Caligarija nekom poznaniku na gradskoj klupi: davno je živio u malom gradu i bio zaljubljen u djevojku Jane. U grad dolazi cirkus i njegov prijatelj Alan ga pozove da pogledaju glasovitu točku dr. Caligarija u kojoj on predstavlja stanovitoga spavača, koji hoda u snu, Cesarea, te koji može predvidjeti budućnost. Tijekom izvedbe Alan pita Cesarea, koji je pod hipnotičkom moći dr. Caligarija, koliko će još dugo živjeti. Cesare predviđa da će Alan umrijeti u zoru. Zgroženi tim predviđanjem, Alan i Francis napuste cirkus, no proročanstvo se obistinilo: Alan je u cik zore ubijen u svojoj kući. Francis posumnja na Caligarija, ali ubrzo se ispostavi da je Cesare ubojica. Cesare otme Jane, ali ga na ulici zaustave ljudi i ubiju. Sam kraj filma usložnjava čitavu priču jer Francis počinje sumnjati u identitet Caligarija: je li on doista upravitelj psihijatrijske ustanove ili pacijent koji se nazvao po znanstveniku iz osamnaestog stoljeća, poznatog po hipnotičkim vještinama. Na kraju opet dolazi do obrata; sve što smo vidjeli bila je Francisova maštarija jer je zapravo on pacijent dr. Caligarija.

Okvirna priča unosi nemir, nesigurnost koja se proteže na čitavu naraciju: je li čitava priča istina ili laž? Ta temeljna dilema, preseljena na pitanje o tome tko je lud, a tko nije lud, je li luđak ispričao čitavu priču, koja bi prema tome bila puka laž (ili fantazija) ili je u pitanju priča zdravog čovjeka, dakle, realna, nešto što se odista dogodilo, dilema je koja muči Kracauera. Ona je još pojačana dilemama koje su morile scenariste, Hansa Janowitza i Carla Mayera, koji su pisali scenarij ispreplićući svoja realna iskustva: Janowitz je vjerovao kako je slučajno bio svjedok ubojstva jedne djevojke u Hamburgu, a Mayer je tijekom ratnih godina nekoliko puta bio podvrgnut psihijatarskom vještačenju zbog mentalnog stanja u kojem se nalazio. Nakon rata, Janowitz, koji je bio oficir i postao pacifist koji često izražava mržnju prema svakom autoritetu, i Mayer, ekscentrični umjetnik s revolucionarnim idejama, sreću se u Berlinu i postaju prijatelji. Jedne su večeri gledali predstavu Čovjek $i$ stroj te 
impresionirani hipnotičkom moći čovjeka-stroja pišu prvu verziju scenarija. Ta verzija scenarija, po Kracauerovu mišljenju, pokazuje ludilo i bolest samoga autoriteta jer se cijela priča odnosi na pitanje individue i institucija. No, tijekom produkcije dolazi do promjene scenarija (promjene koju je inicirao redatelj Wiene, a kojoj su se usprotivili Janowitz i Mayer) i u toj novoj verziji lik Francisa uokviruje cijelu priču, što dovodi, po Kracauerovu mišljenju do slavljenja autoriteta kao svojevrsne zaštite od ludila. Međutim, Kracauer u svojoj analizi ne spominje moment koji mi se čini izuzetno važnim, a to je pitanje dosega moći autoriteta, naime, je li Caligari odista najsnažniji lik čija hipnotička moć nema granice?

Gledajući iznova i iznova taj film, posebno zagonetnom doima se scena koja mi je ranije promicala: na samom početku Caligari dolazi u gradski ured i traži dozvolu za cirkus. Od samoga početka nešto u toj sceni 'nije u redu': Caligari, kao i svaki poslušni građanin, prisiljen je čekati, natkriljen najobičnijim gradskim činovnikom koji sjedi na visokoj rotirajućoj stolici. Zašto je tako moćni hipnotizer koji čak može pokrenuti i hipnotizirati žive mrtvace prisiljen uredno čekati? Zašto je toliko beznačajan u usporedbi s najobičnijim službenikom koji sjedi na visokoj stolici? Upućuje li ta scena na širu mrežu odnosa u kojima je birokracija moćnija od hipnotizerove manipulacije živim mrtvacima? Sve te razne tendencije, rastresenosti i rastrganosti objedinjuju se kroz prizmu birokracije koja, međutim, i sama obdarena posebnom moći, ostaje neprepoznatljiva, nedorečena - kafkijanska.

Postavlja se pitanje o tome duguju li Janowitz i Mayer tu fantastičnu dimenziju birokracije činjenici da su i jedan i drugi iskusili birokraciju Austro-Ugarske, tj. onome što Hannah Arendt zove pseudo-mističnom aurom arbitrarne birokracije. ${ }^{25}$ Arendt primjećuje da ta imperijalna birokracija uvelike podsjeća i prethodi kasnijem totalitarizmu, nacizmu, radikalnoj bio-političkoj administraciji koja transformira sve državne institucije u forme tanato-političke birokracije. Birokratski stroj, zamršen, nedokučiv perifernoj populaciji, neprestano izdaje nove, nerazumljive dekrete, nedokučive uredbe, koju opravdava neka daleka i mistična moć. Ona je odista kafkijanska i čini austrougarske podanike sitnim, nevažnim, bespomoćnim, ali istovremeno, nošeni su transnacionalnim panslavenskim idejama, isto tako (doduše na drugi način) nedokučivim zanosom neke nadolazeće sile. Bivši subjekti Austro-Ugarske, Janowitz i Mayer, oslikali su tu podvojenost, barem u tom trenutku, i na samoga Caligarija: ne radi se samo o uživanju u rađanju tiranske moći, kao što to tvrdi Kracauer, nego i o osjećaju bespomoćnosti, podložnosti birokratskoj mašineriji. Zato Caligari čeka u uredu, ispred glomazne, visoke stolice na kojoj sjedi činovnik.

$\mathrm{U}$ toj sceni vidim moment $\mathrm{u}$ koji se sve slijeva, ali čak ni u tom slijevanju ne ostavlja dojam jedinstvenosti, već iste ili slične rastrojenosti i rastresenosti koje Deleuze pronalazi u kafkijanskoj pisaćoj mašini. ${ }^{26}$ Raspadanjem,

24

Usp. S. Kracauer, From Caligari to Hitler, str. 61-76.

25

Hannah Arendt, The Origins of Totalitarianism, Harcourt, New York 1975., str. 243-244. Usp. E. L. Santner, »Of Kings and Other Creatures«, u: E. L. Santner, The Royal Remains, str. 33-63.
26

Usp. Gilles Deleuze, Cinema 1. The Movement-Image, preveli Hugh Tomlinson, Barbara Habberjam, University of Minnesota Press, Minneapolis 1986. 
gnjiljenjem austrougarskog imperijalnog tijela, tj. u tim prelaznim trenucima, Deleuze uočava neobične procese: oslobađanje forme od sadržaja, $\mathrm{tj}$. same forme postaju intenziteti (atonalna ljestvica, kubističko slikarstvo, avangardni eksperimenti). Kafkijanska pisaća mašina ispisuje tekstove prijelomnog prijelaza na razne popularne oblike suverenosti, koji odzvanjaju bliskom budućnošću: budući fašizam, komunizam, Staljinizam, američki konzumerizam - klice budućih totalitarizama koji se kriju u modernizmu, ali još uvijek nisu okoštale u hijerarhije, $u$ forme. Pitanje je koliko su intenziteti bez određenog sadržaja koje slavi Deleuze ikada bili slobodni, a koliko prožeti Schreberovim kozmičkim zrakama.

To čekanje dozvole, mislim, naslućuje promjenu paradigme koju Kracauer nije bio u stanju vidjeti: svu tu disperzivnu prisutnost raznolikih totalitarizama svodi pod jednu, jedinstvenu tiransku moć koja, po njegovu mišljenju, dolazi iz tamnih srednjovjekovnih dubina napućenim somnambulistima i čarobnjacima. Kracaurerov argument proizlazi iz njegova teorijskog polazišta utemeljenog na frankfurtskoj školi - ideja da se u čitavom tom psihoanalitičkom razmatranju nadolaska nacizma ipak na kraju može nazrijeti neki zdravi dio ljudske psihe koji se ne može samo tako zaraziti, zauzeti, obuzeti. Zbog toga Kracauer brani Janowitzovu i Mayerovu verziju scenarija u kojoj su stigmatizirali »svemoć državne moći koja se odražava u univerzalnom novačenju i pravu na objavu rata«. ${ }^{27}$ Tako na kraju i Kracauer postavlja opoziciju tiranskoj moći u zdravom jezgru ega. Ali, kao što smo već vidjeli kod Schrebera i njegovih »božanskih zraka«, Caligari nije jedini koji vlada, njegova hipnotička moć podložna je birokratskoj mašini. Baš kao i kod Schrebera, nema djevičanske, čiste unutrašnjosti, ona se više nikako ne može zaštiti, u nju prodire birokracija. Upravo to prelaženje institucija u subjekt donosi problem prikazivanja tog prožimanja: filmska imaginacija lomi se u raznim smjerovima (čudovišnosti, pristajanje na demonsku moć), miješa se s raznim arhetipovima i mitovima, prijašnjim vremenima. Kao što Santner tvrdi, ta tiranija proizlazi iz duboke krize institucija i suverene moći u modernizmu. Ta kriza, istovremeno zamaskirana raznim čudovištima, fantomima, dvojnicima i replikantima, potiskuje ili prikriva kafkijansko širenje birokratske mašine u sve sfere društva. Tu se ne radi o birokraciji koja 'oduzima čaroliju' svijetu, birokraciji koja isušuje kaljužu praznovjerja i iracionalizma, već upravo suprotno, možemo reći da se tu radi o 'očaravanju birokracije' - nedokučiva čarolija birokracije seže dublje i dublje u srž pojedinca, protežući se na sve oblike društvenosti.

\section{Što se sve još krije u sjenama njemačkog ekspresionizma?}

Opće je poznata činjenica da njemački ekspresionizam obiluje sjenama koje kreiraju prijeteći prostor. Isto tako, te se sjene uglavnom svode na stilska obilježja filmskog i šireg kulturnog pokreta. U tim sjenama, međutim, možemo iščitati puno više, nego što bismo u prvi mah očekivali. Thomas Elsaesser u svojoj knjizi Weimar Cinema and After: Germany's Historical Imaginary, $\mathrm{u}$ osvrtu na Kabinet doktora Caligarija vidi nešto što se u danom povijesnom trenutku nije dalo izraziti, što se opiralo objašnjenju, a ipak pomaljalo u filmskim slikama (u sjenama) ${ }^{28}$ - dakle, nešto neizrecivo. Zagonetnost sjena, među ostalim, potječe iz povezivanja dvaju ili više različitih prostora - ono što zasjenjuje i ono što tone u sjenu (one su i metafora odnosa unutarnjega $\mathrm{i}$ vanjskoga). Za Kracauera je ekspresionistički film svojevrsna projekcija unutarnjih duševnih stanja prema van, »fenomen svega što se vidi zapravo je 
fenomen projicirane duše « ${ }^{29} \mathrm{U}$ svakom slučaju, prostorne mijene nisu samo pitanja estetike i scenografija; one izražavaju »strukturu duše kroz oblikovanje prostora «. ${ }^{30}$

Deleuze u sjenama vidi mogućnost bijega, ulaženja u neki drugi prostor: sjene poništavaju danosti prostora, izbavljaju nas iz skučene determiniranosti i mogu postati bilo koji prostor. ${ }^{31}$ Baš kao što poništavaju prostore, sjene ujedno i stvaraju prostore, sugeriraju neki nepoznati život, čudno neorgansko postojanje. U dalekim križanjima ulica ili ukošenim zgradama, u gotičkim dubinama, prostor se urušava upadajući u crne rupe ili uzdiže ulaženjem svijetla. Dakle, u sjenama njemačkog ekspresionizma Deleuze vidi prostore koji još nisu zahvaćeni kafkijanskom birokratskom mašinom, mogućnost bijega - spasa.

Za mene su sjene više stanje izvanrednoga stanja. Ako promišljamo santnerovski cijelu scenografiju u Kabinetu doktora Caligarija, pod režimom biomoći gdje življenje postaje scena koja je administrirana, disciplinirana i regulirana, onda možemo reći da svojevrsni neizrecivi višak (sublimno meso) ima učinke i preobražava čitav urbani prostor: velike glomazne stolice na kojima se rotiraju svemoćni birokrati; ogromna stolica u Alenovoj sobi materijalizira njegovu tjeskobu koja ga pritišće, umanjuje, guši; tavani koji pritišću sa svih strana kao da tirani odozdo gledaju intimne trenutke svakodnevnice; vijugave, spiralne stepenice utjelovljuju živčanu napetost itd. Snažni kontrasti svijetla i tame kao da potiskuju sivilo osrednjosti, sivilo normalnosti, svijetlost putem sjena koristi zidove da bi uprizorila ubojstvo (Alenovo ubojstvo prikazano je kao igra sjena), proizvodeći dojam halucinacije. Iz toga stanja izviru iskrivljene panorame, kosi rakursi izobličuju lica u ulice, šiljaste i trokutaste plohe, ukošene kuće i ulice, snažni kontrasti svijetla i sjene, sve to prerasta u vizualni 'caligarizam' koji obuhvaća urbano tkivo čitavog grada. Demonski autoriteti, dvojnici, golemi i podvojene ličnosti kao da su stopljeni s tim prostorom - život se odvija u neprestanom očekivanju uzbune, u permanentnom izvanrednom stanju. Kao da su urbane vedute nastale zahvaljujući projekciji Schreberovih božanskih zraka. ${ }^{32}$

Za Giorgija Agambena izvanredno stanje - exception - nije nešto izvan Zakona, u svom zasebnom prostoru. Dapače, izvanredno stanje proizlazi iz suspenzija Zakona; sam Zakon donosi neku vrstu privremenog bezakonja, odsustvo Zakona, nešto što Zakon ne regulira, stoga se gube granice između unutra i vani, između sigurnog i opasnog, poznatog i nepoznatoga. ${ }^{33}$ Kao što Santner

27

S. Kracauer, From Caligari to Hitler, str. 64.

28

Usp. Thomas Elsaesser, Weimar Cinema and After. Germany's Historical Imaginary, Routledge, London 2000., str. 420-445.

29

S. Kracauer, From Caligari to Hitler, str. 71.

30

Ibid., str. 75.

31

»Kako bilo-koji-prostor može biti iz stanja stvari, iz determinirajućeg prostora. Pravi put su sjene, sjene: prostor pun sjena, ili prekriven sjenama, može postati bilo koji prostor.« G. Deleuze, Cinema 1, str. 111-112.

32

Pitanje je što se krije u sjenama njemačkog ekspresionizma, u svijetu osuđenom na monokromatsku dramatiku, u svijetu bez boje. Je li uopće - bez obzira na to što su ti filmovi nastali u crno-bijelom periodu, moguće zamisliti boju u Kabinetu Dr. Caligarija ili Golemu? Koja bi to boja bila? Je li uopće moguća boja u svijetu sjena?

33

Usp. Giorgio Agamben, Homo Sacer: Sovereign Power and Bare Life, preveo Daniel 
ističe, to je jedno od najvažnijih aspekata političke teologije i pravo suverena da donese odluku o izvanrednom stanju ${ }^{34}$ dosežući univerzalnost upravo $\mathrm{u}$ mogućnosti svoga dokidanja. ${ }^{35}$ Sjene kao naznaka izvanrednoga stanja mogu proizvesti brojne Caligarije koje će hipnotizirati i voditi mase Cesarea; one su hipnotička dimenzija ideologije.

Štoviše, u modernizmu izvanredno stanje obuhvaća sve pa i samu znanost, materiju, stvoreno, stvorenja i stvaratelja u zamršenom spletu biomoći. Kada se znanost, eksperti, političari (sve prožeto birokracijom) počnu baviti životom pojedinca, populacije, nacije u izvanrednom stanju, dolazimo do života kao takvog, golog života o kojem govori Agamben. Te se naznake već vide i u njemačkom ekspresionizmu, u sjenama koje nisu samo puka stilska obilježja. U njima se krije neorganski život, život stvari, stvorenja ili stvoreno; one čine stvarnost bez stvoritelja, umjetne tvorevine koje se na razlikuju od mehaničkih i organskih tvorevina, gubljenje granica između živih i mrtvih oblika postojanja. Proces je to koji oslikava krajnje domete biomoći: kada život postaje objektom politike, kao da je sama materija u izvanrednom stanju. Stoga u tom prostoru historicizma - svi mi postajemo stvorenja, i čudovišta i usamljeni pojedinci u metropolama, stvorovi koji su izgubili smisao jer više ne znaju ni tko im je stvoritelj, ni što stvoritelj zahtijeva od njih.

\section{Caligarijeva ostavština}

Pitajući se o tome koliko povijesti ima u filmu te koliko filma u povijesti, tj. koja je uopće veza povijesti i filma, Elsaesser pokušava nanovo procijeniti »Caligarijevu ostavštinu«, a film promatra kao svojevrsnog dvojnika povijesti. ${ }^{36}$ Naravno, postavljajući vezu dvojnika između povijesti i filma pitanje se širi na povijest, ali isto tako, imajući u vidu zlokobno djelovanje dvojnika (što je promaknulo Elsaesseru) i na nešto strano i sablasno u povijesti što može obitavati u našoj sadašnjosti, tj. imati učinke na povijesnost u našoj sadašnjosti. Slažem se s njim da je povijesni trenutak Weimarske Republike - galopirajuće inflacije, klasni nemiri i neslućene seksualne slobode - vapio za odgovarajućim filmskim slikama da bi sama povijest bila vidljiva, tj. prepoznatljiva. Elsaesser uz temu filma kao dvojnika povijesti uvodi i sjenu, tj. tvrdi da su filmovi postali sjena koje je uvela »neizrecivo« u određeni povijesni trenutak. Film kao sjena koja ulazi u zbilju ili kao dvojnik povijesti u sebi i dalje ostavlja otvorena pitanja koja daleko premašuju okvire Weimarskog razdoblja ili dolazak nacizma na vlast. Proširujući te dileme na nastanak filma noir u Americi i globalni neo-noir i postmodernu nacističku ikonografiju, Elsaesser tu zastaje, dok su meni i dalje od presudne važnosti te sjene - koje izražavaju neizrecivo - što je to neizrecivo u predmetima, pojavama stvarima - što je to nevidljivo u filmskim slikama? Možda se sve to može svesti i na pitanje: kako se film kao dvojnik povijesti odnosi prema tim sjenama? Taj povijesni dvojnik - sablast filma - nikako ne može otkriti svoje mračne korijene ili ne može nikako osmisliti do kraja svoju političku teologiju, opterećen tom sablasnom drugošću. Mislim da se to »neizrecivo u sjenama« koje navodi Elsaesser treba svesti, puno konkretnije, na bacače sjenki, na onoga koji zasjenjuje, tako ćemo barem, iako ne do kraja, odgonetnuti što se krije u tami sjene, barem naznačiti moguće puteve potrage.

Smatram da film kao dvojnik povijesti svoje sjene duguje tranziciji od duhovne do svjetovne vlasti, od monarhističke do narodne suverenosti. Od monarhije do nacionalne zajednice u zajedničkim okviru koji čini država (nacije su 
nastale u ritualnom, ontološkom nasilju - u stravi i užasu, koji kasnije neprestano ili potiskuju ili slave kao zajedničku patnju). U svojim najdrastičnijim, najdramatičnijim oblicima svrgavanje kralja, tj. uklanjanje kralja s pozicije autoriteta (njemački je izraz za to Entsetzen) ujedno označava i horor; ${ }^{37}$ a horor nas smješta u semantičko polje, u sami izvor »utemeljiteljskog nasilja« koje uspostavlja samo »političko«, tj. novi oblik realnosti u kojoj bi trebali živjeti (polje vidljivog prelazi sa sakralnog u profano). Drugim riječima, tim činom sve vidljivo postaje ideologija (u raznim modusima), tj. vidljivo postaje ono što sjene nisu prekrile, ali kao i u izvanrednom stanju, one neprestano ugrožavaju vidljivo unoseći negativnost $u$ filmsku sliku, iluziju skrivene istine (za Elsaessera, neizrecivo u povijesti ispoljava se kao negativno u filmskoj slici). ${ }^{38}$ Mislim da se to neizrecivo isto tako može odnositi na nove oblike narodne suverenosti te se može iščitati u sivkasto praznom prostoru iza blijedog, mrtvog Marata - to sivilo praznine ukazuje na nemogućnost prikazivanja novonastalog tijela mnoštva, meso koje više ne pripada kralju postaje apstraktno i sablasno podriva polje vidljivoga.

Kako prikazati to novo tijelo koje dolazi na mjesto kralja, tj. novi oblik suverenosti, može li se ono uopće prezentirati? Raspadnuto meso ili meso koje više nije stegnuto u jednu anatomiju - onu kralja (nošeno starim političko-teološkim kosturom) - rasplinjuje se u sivilo pozadine (koja pokušava nadomjestiti »anatomiju« suverenog naroda). ${ }^{39}$ To stanje signalizira neprestanu krizu prezentacije koja upravo proizlazi iz toga neizrecivoga, dok je sam čin, na kojem počiva nova suverenost, potisnut baš kao i utemeljiteljsko nasilje u uspostavljanju Zakona.

Filmski način proizvodnje, po meni, pokušaj je predstavljanja tog corupsa misticuma, čak i u pokušajima otkrivanja careve golotinje (carevo novo ruho) uvodi političku teologiju u našu svakodnevnicu, daleko više nego što bismo ikada pretpostavljali. Katkada se to odvija u krajnje vulgarnom i pojednostavljenom obliku: tako za Kracauera film kao dvojnik povijesti pretvara cijelo njemačko društvo u filmski set: brojni Homunculusi šeću se ulicama; mnogobrojni Caligariji hipnotiziraju razne Cesareve da počine ubojstva; pomahnitali Mabuseji čine zločine za koje ne odgovaraju. ${ }^{40} \mathrm{Za}$ Kracauera, čitav njemački film tako je uspostavljen teološki, ima teološku svrhu, sva ta prethodna djeca svjetlosti vode do jednog tijela, tijela totalitarnog vođe, sublimno tijelo mo-

Heller-Roazen, Stanford University Press, Stanford 1998.; Eric L. Santner, On Creaturely Life: Rilke, Benjamin, Sebald, Chicago University Press, Chicago 2006., str. 86.

34

Za Carla Schmitta, logika suvereniteta počiva na izvanrednom stanju, tj. konstituiranje prostora pravne normativnosti uključuje referencu na izvanredno stanje u kojem suveren ima moć suspendirati pravo (zakon) u ime zaštitite sigurnosti same države, kreirajući granicu između 'nas' i ‘drugih', granicu koja je utemeljena na političkoj odluci - izvanjsku granicu koja podrazumijeva unutarnju podjelu između zakona i njegove imanentne izvanjskosti. Usp. E. L. Santner, On Creaturely Life, str. 13-14.

35

Tom odlukom istodobno umnaža i one koji su isključeni, odbačeni, 'ljudsko smeće'.
36

T. Elsaesser, Weimar Cinema and After, str. 35 .

37

E. L. Santner, The Royal Remains, str. 61.

38

T. Elsaesser, Weimar Cinema and After, str. 35 .

39

E. L. Santner, The Royal Remains, str. 92.

40

S. Kracauer, Weimar Cinema and After, str. 272 . 
narha ponovno oživljeno u novim oblicima apsolutne moći ili barem njezinog privida. A sve to završava - u toj vulgarnoj političkoj teološkoj liniji razvoja - dolaskom Hitlera na vlast.

Suprotno tome, politička teologija filma, kakvu pokušavam ustanoviti, nije nužno upletena u pravolinijski povijesni narativ: ona se bavi imanentnom proizvodnjom filmskih slika. Po mom mišljenju, upravo Schreber sa svojom "neuro-teološkom « bolešću upućuje na hipnotizam doktora Caligarija, otvara prostor dijaloga te nas taj duo povezuje s neočekivanom, novom bolešću institucija koje nastaju u modernizmu. Ta bolest birokracije u sebi katkada sadrži magičnu moć, kako to opisuje Arendt, a Santner obogaćuje s teološkom dimenzijom Schreberove bolesti, označavajući je tajnom poviješću modernizma (naznačujući da ta bolest vodi, među ostalim, i do libidinalne ekonomije nacizma). ${ }^{41}$ Važno je naglasiti da u tome vidim krizu predodžbe koja se tiče i filmskoga načina proizvodnje, tj. kako uopće predočiti tu proizvodnju društvenog tijela upletenog u sablasnu drugost suverenosti oblikovane s biomoći.

Kad god pokušamo direktno pokazati to tijelo mnoštva (sivu pozadinu iza mrtvoga tijela Marata), onda se gubi balans, kao da je u istom trenutku priroda i društvo snažno bačeno u izvanredno stanje, iz kojega iskaču razna moderna i postmoderna čudovišta. Možda se to već događalo i u sjenama njemačkog ekspresionizma, ali to nismo primijetili. Daleko od toga da su sva ta čudovišta ili čudovišnosti puko vraćanje u stara vremena, arhetipovi i mitovi prošlosti, u njima postoji neodređena slutnja i prijetnja ponikla u samom modernizmu. Prije svega, u projiciranju unutarnjih strahova i tjeskoba prema van (eksternalizacija): odraz praškog studenta u zrcalu kojim manipulira demonski čarobnjak, hrpa gline iznenada oživljena i uljuđena koja kreće u krvoločni osvetnički pohod, ljudsko tijelo proizvedeno u laboratoriju. U svim tim primjerima dolazi do materijaliziranja strahova, do novih oblika života kojima neko bezdušno manipulira, iako je taj život sjena sablastan kao da je još užasnija činjenica manipulacije, kontrole (kao u slučaju Schrebera kao redatelja, kojeg režira drugi redatelj), dakle, snažan odnos stvoritelja i stvorenoga, stvoritelja kao Gospodara i stvorenoga kao roba, poslušnika - političko-teološki aspekt. Je li i danas taj snažno teološko-politički odnos stvoritelja i stvorenoga prisutan? Je li potisnut na marginu? Iz svega ovoga, čini mi se, proizlaze dvije ekstremne krajnje suprotne mogućnosti: s jedne strane, snažna prisutnost Stvoritelja kao manipulatora, a s druge strane, njegova potpuna odsutnost. Te su strane međusobno ovisne ili samo naličje jedne strane, koja počinje s prividom gubljenja teološko-političke dimenzije (npr. u globalnoj ekonomiji, globalizaciji, tj. pojednostavljeno »više nitko ne zna gdje ovaj svijet ide«, nisu ni postavljeni nikakvi parametri, ciljevi, svrha se odavno izgubila). Čini se da gospodar, stvoritelj sve više nestaje ugrozom humanizma i filozofije, kojom bismo moguće detektirali novog gospodara. Po mišljenju nekih i sama oruđa filozofije bivaju ugrožena: jezik, logos, simbolično - jer slike preplavljuju sve vidove komunikacije, preuzimaju jezik, postaju parazitski šumovi na jeziku, tehnika slike djeluje brzinom svjetlosti, jezik je prespor, ne može više usporiti svijet infosfere. Stoga neki filozofi, kao na primjer Wlad Godzich, smatraju da "živimo usred predlogičke afirmacije svijeta, u smislu da se on događa prije činjenice logosa i on nam prijeti takvim otuđenjem kakvo moderni mislioci jedva mogu zamisliti ${ }^{42}$

Tu dijagnozu o globalnoj naplavini imaginarnoga možemo prevesti i na slučaj Schrebera, pogotovo na gubljenje razmaka u simboličnom, odstojanja od institucija ili, Lacanovim rječnikom (kojim je izražena i njegova dijagnoza), 
gubljenje Imena Oca, što rezultira utapanjem simboličnog u Realnom ili plaženje Realnog po svim vidovima simboličnog, posebno u globalnoj virtualnoj mreži. Takva dijagnoza glasi: psihotično stanje. U perverznom vidu čak i kao parodija umjetne inteligencije $u$ korijenima neuroznanosti, tj. odnosu mozga i stvarnosti, koja je u svojim začecima prisutna kod Schreberova doktora. Flechsig je bio pionir neuroznanosti, secirao je mozgove duševnih pacijenata da bi doznao vezu između mozga i duševnih bolesti, a u kasnijoj fazi svoje karijere nastojao je - po njegovu mišljenju uspješno - pronaći dijelove mozga i živaca koji odgovaraju filozofskim postulatima, uključujući i Kantov transcendentalni idealizam) ${ }^{43}$ Flechsig je taj drugi 'redatelj' koji neprestano mobilizira Schreberov mozak, stavlja njegove živce u izvanredno stanje, ali na kraju i on biva potisnut. Schreber u svojim memoarima piše:

»... kasnije, bez obzira na nerve profesora Flechsiga, božanske zrake direktno su ušle u kontakt s mojim živcima. Taj je utjecaj tijekom godina preuzeo oblike u kontrastu sa Svjetskim Poretkom i ljudskim naravnim pravom da bude gospodar svojih živaca i ja sam, priznajem, postao groteskan. $\ll^{44}$

U svom psihotičnom stanju Schreber neprestano i iznova proizvodi paranoične narative, koji su slični postmodernom paranoičnom čitanju svijeta. S jedne strane, ta očajnička potraga za demonskim Manipulatorom jest ustvari paranoično osluškivanje vibracija sablasnog rojalističkog mesa u beskrajnoj igri označitelja i označenoga, u digitalnoj dezertifikaciji afektivnoga života, u biomoći, u globalnom strujanju slika; postaje samo nesvjesno globalnog spektakla. Otuda i paranoje, drugim riječima, očajnička potraga za Manipulatorom, za zlim Drugim koji manipulira nas same i svijet oko nas i čitavu planetu. U valu rastućeg populizma, kako europskom tako i šire, danas je ta potraga nošena nacionalnim paranojama koje čak i u globalnom zatopljenju vide masonsku zavjeru ili strepe pred vanzemaljcima kao prijetnji svjetskim religijama, da ne govorimo o imigrantima i izbjeglicama koji »kao zombiji orkestrirani židovskim mešetarenjem s globalnim financijama« navaljuju preko granica - sve to ugrožava opstojnost nacije. Sve to ugrožava zdravo tijelo obitelji, radost nerođenih fetusa i nevino čisto zdravo tijelo nacije. Schreberova psihoza prerasta u normu.

$\mathrm{S}$ druge strane, može se reći da u suvremenim postmodernim filmovima stvoritelj, kreator nestaje; ostaje samo čudovište. Umjesto Caligarija u prvi plan dolazi Cesare, samostalan, ali obezglavljen, bez gospodara: stvorenje se osamostaljuje; sablasni život postaje zasebni entitet - stvor. Stvor svjedoči o raskolu u samom životu, život-u-životu, tijelo-u-tijelu monarha, sublimno tijelo, otkačivši se postaje prijeteća sablast koja se munjevitom brzinom giba po čitavoj zemaljskoj kugli. Svi oni manipulatori u njemačkom ekspresionizmu nestaju, demonski autoritet nestaje te se čini da se glina Golema, odrazi praškog studenta, proizvedeni homunkuli, kreću sami od sebe, kao kantijan-

41

Vidi: E. L. Santner, My Own Private Germa$n y$, str. 9. Santner ističe kako mobiliziranje masa u nacizmu nije moguće bez shvaćanja paranoidnih mehanizama i narativa koje već nalazimo u Schreberovim memoarima, tj. njegovoj paranoji.

42

Prema: J. Beller, Kinematički način proizvodnje, str. 127.
43

E. L. Santner, My Own Private Germany, str. 71

44

Ibid. 
ska stvar-po-sebi postaju čudovišta-sama-po-sebi, apsolutna Drugost materije i energije koja bezglavo prijeti opstanku čovječanstva. ${ }^{45}$ Tako oživljena, otkačena osamostaljena biomoć (bez suverenosti) ${ }^{46}$ postaje puki goli život koji se giba svemirskim i zemaljskim bespućima. S vremenom ili posve naglo to društveno tijelo narodne suverenosti pretvoreno u čudovište postaje ugroza svim ustaljenim oblicima života, bez ikakve svrhe (telosa), bezumlje se čini potpuno besmisleno.

\title{
Mario Vrbančić \\ The King without Body and His Shadow
}

\section{Towards a Political Theology of Film}

\begin{abstract}
Inspired by the work of Eric Santner (1996, 2011) on political theology and the king's two bodies, in this paper, I question the political theology of film. I analyze how the carnal dimension of sovereignty (or king's second body, the body of his power), migrates into a new body, the body of the people, and in various traces appears in the filmic mode of production that marked the twentieth century. I analyse or instead bring into imaginary connection two characters (one real, the other fictional) who in a way embody this migration: (1) Judge Daniel Paul Schreber (whose autobiographical record of mental illness, from the moment it was published (in 1903), occupied the attention not only of psychiatrists and psychoanalysts but also of various theorists) and (2) Dr. Caligari, a hypnotist in the film The Office of Dr. Caligari (dir. Robert Wiene, 1920), one of the most famous characters of German expressionist film.
\end{abstract}

\section{Keywords}

political theology of film; king's two bodies, biopower, cinematic mode of production, psychoanalysis

45

Usp. Mario Vrbančić, The Lacanian Thing: Psychoanalysis, Postmodern Culture and Cinema, Cambria Press, New York 2011.

46

Zahvaljujem Gordanu Maslovu koji mi je skrenuo pozornost na ovaj aspekt biomoći kod Foucaulta. »Moć da se proizvodi i koristi atomska bomba predstavlja uvođenje suverene moći koja ubija, ali je također moć ubiti sam život. Dakle, moć koja se upražnjava u ovoj atomskoj snazi upražnjava se na taj način da samo sebe može potisnuti. Dakle, potisnuti do te mjere da je moć koja garantira život. Ili je suveren pa iskoristi atomsku bombu, te time ne može biti moć, biomoć, moć koja garantira život, ili, u ekstremnoj suprotnosti, više nemamo suvereno pravo s viškom biomoći, već je to biomoć s viškom suverenog prava." - Michel Foucault, Society Must Be Defended. Lectures at the Collège de France, 1975-76, preveo David Macey, Picador, New York 2003., str. 253-254. 